(1) Nordic Council of Ministers

\title{
Nordic \\ Economic \\ Outlook \\ 2017
}

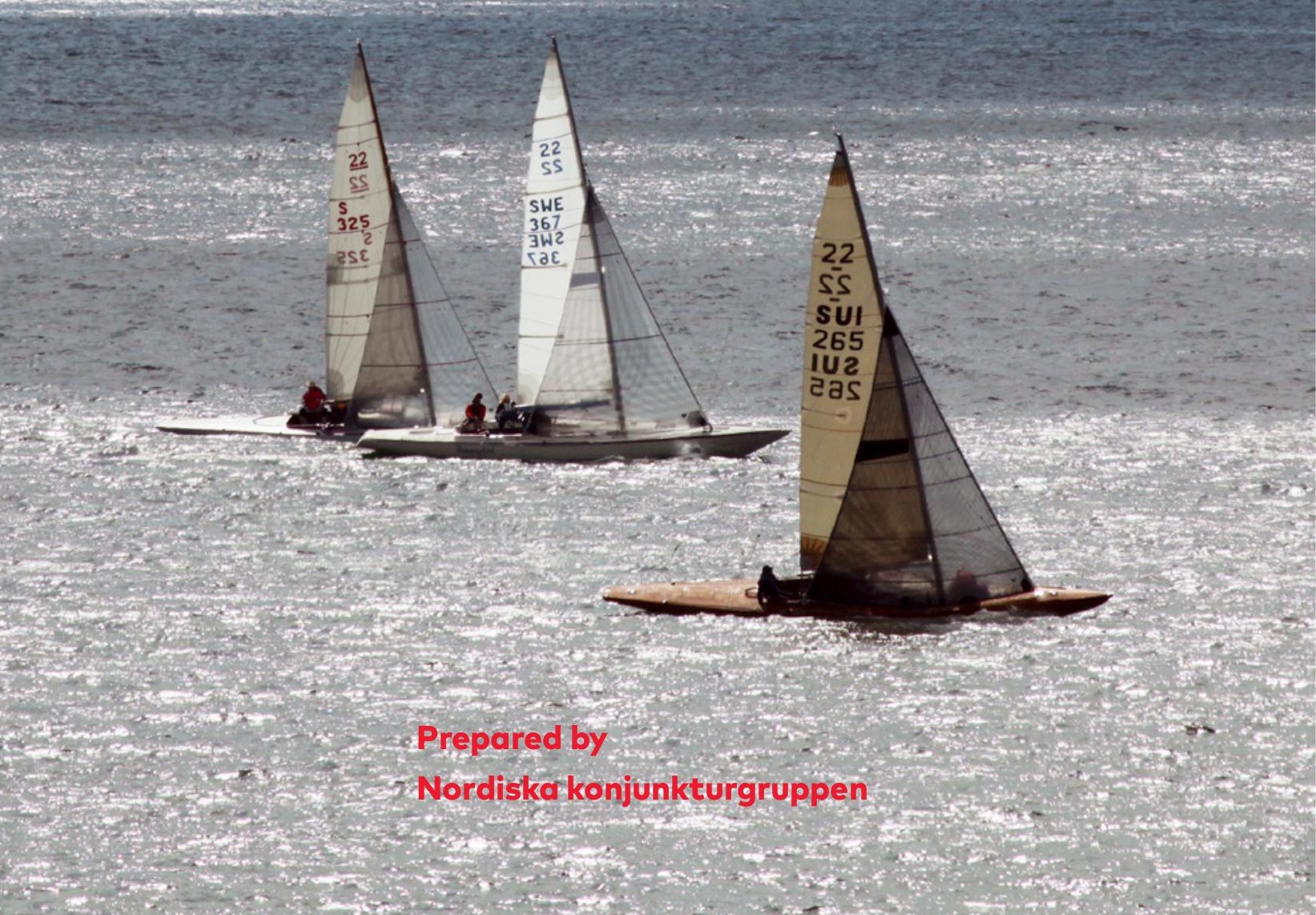



Nordic Economic Outlook 2017

TemaNord 2017:568 


\section{Nordic Economic Outlook 2017}

ISBN 978-92-893-5262-8 (PRINT)

ISBN 978-92-893-5263-5 (PDF)

ISBN 978-92-893-5264-2 (EPUB)

http://dx.doi.org/10.6027/TN2017-568

TemaNord 2017:568

ISSN 0908-6692

Standard: PDF/UA-1

ISO 14289-1

(c) Nordic Council of Ministers 2017

Cover photo: Jan Klingeborn

Print: Rosendahls

Printed in Denmark

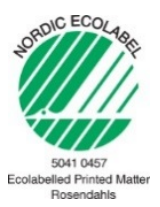

Disclaimer:The content of this joint report is based on official Government documents from the Nordic countries. However, the opinions expressed in the text are those of the members of the Nordic Group of Macro-Analysts (Nordiska konjunkturgruppen), and do not necessarily reflect the official views of the Nordic countries.

\section{Nordic countries. Rights and permissions}

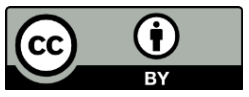

This work is made available under the Creative Commons Attribution 4.0 International license (CC BY 4.0) https://creativecommons.org/licenses/by/4.0.

Translations: If you translate this work, please include the following disclaimer: This translation was not produced by the Nordic Council of Ministers and should not be construed as official. The Nordic Council of Ministers cannot be held responsible for the translation or any errors in it.

Adaptations: If you adapt this work, please include the following disclaimer along with the attribution: This is an adaptation of an original work by the Nordic Council of Ministers. Responsibility for the views and opinions expressed in the adaptation rests solely with its author(s). The views and opinions in this adaptation have not been approved by the Nordic Council of Ministers. 
Third-party content: The Nordic Council of Ministers does not necessarily own every single part of this work. The Nordic Council of Ministers cannot, therefore, guarantee that the reuse of third-party content does not infringe the copyright of the third party. If you wish to reuse any third-party content, you bear the risks associated with any such rights violations. You are responsible for determining whether there is a need to obtain permission for the use of third-party content, and if so, for obtaining the relevant permission from the copyright holder. Examples of third-party content may include, but are not limited to, tables, figures or images.

Photo rights (further permission required for reuse)

Any queries regarding rights and licences should be addressed to:

Nordic Council of Ministers/Publication Unit

Ved Stranden 18

DK-1061 Copenhagen $\mathrm{K}$

Denmark

Phone +4533960200

pub@norden.org

\title{
Nordic co-operation
}

Nordic co-operation is one of the world's most extensive forms of regional collaboration, involving Denmark, Finland, Iceland, Norway, Sweden, and the Faroe Islands, Greenland and Åland.

Nordic co-operation has firm traditions in politics, economics and culture and plays an important role in European and international forums. The Nordic community strives for a strong Nordic Region in a strong Europe.

Nordic co-operation promotes regional interests and values in a global world. The values shared by the Nordic countries help make the region one of the most innovative and competitive in the world.

\author{
The Nordic Council of Ministers \\ Nordens Hus \\ Ved Stranden 18 \\ DK-1061 Copenhagen K, Denmark \\ Tel.: +4533960200 www.norden.org \\ Download Nordic publications at www.norden.org/nordpub
}





\section{Contents}

Summary

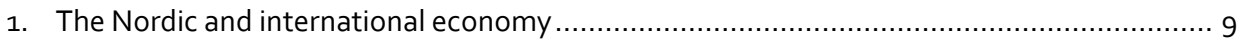

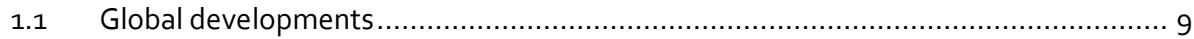

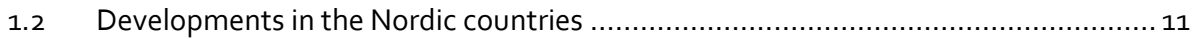

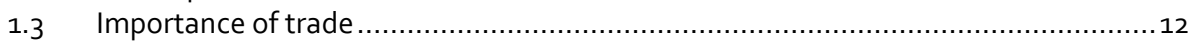

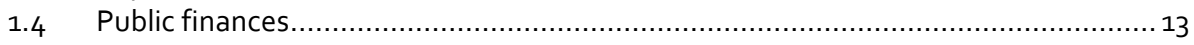

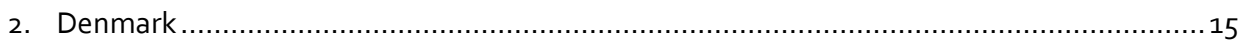

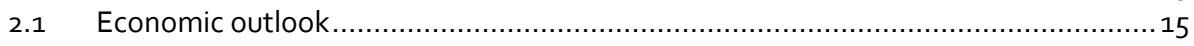

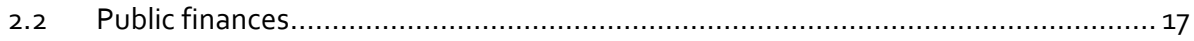

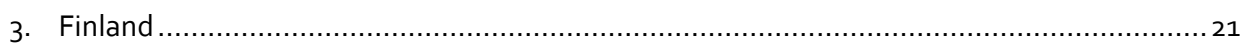

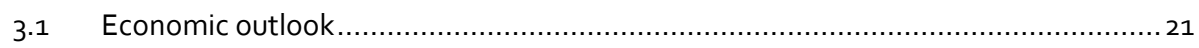

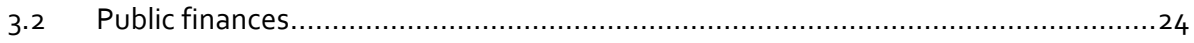

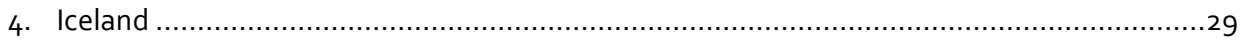

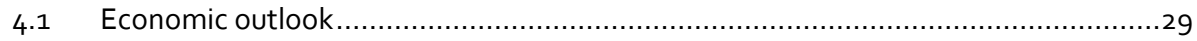

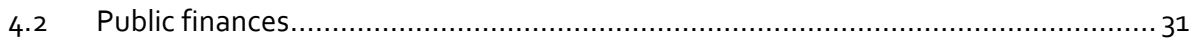

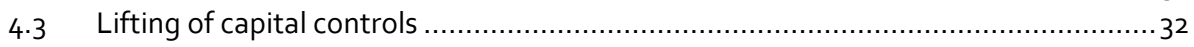

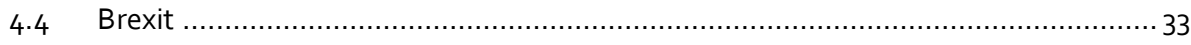

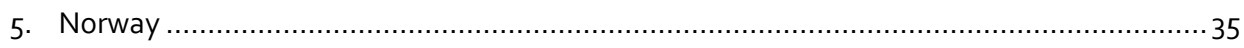

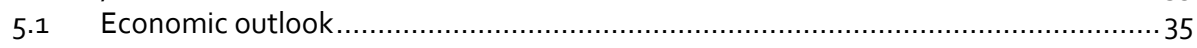

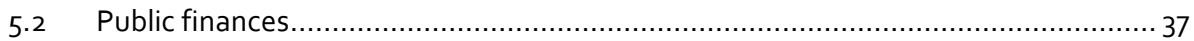

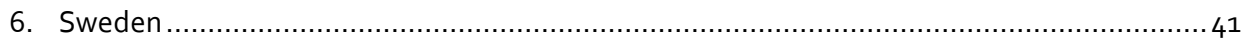

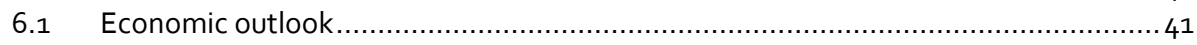

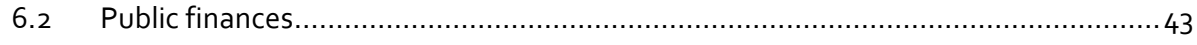

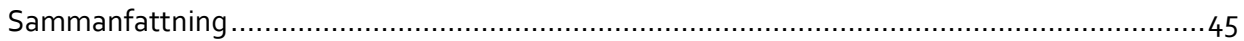





\section{Summary}

This report of economic development in the Nordic countries has been prepared by the Nordic Group of MacroAnalysts (Nordiska konjunkturgruppen). The Nordic countries are in different phases of the business cycle. Danish GDP growth is broad, with the largest contributions expected to come from private consumption and exports, while investments will become a more significant contributor in 2018. The Finnish economy is in a phase of rapid growth. Private consumption and, to some extent, investment demand growth will slow, but exports will pick up. The downturn in Norway has come to an end. Targeted fiscal policy has served to promote growth and reduce unemployment. Mainland GDP growth is projected to exceed trend next year. The activity level in the Swedish economy is high. The government's welfare initiatives, together with household consumption and investments, contribute to continued strong growth. The Icelandic economy is growing strongly. The growth is export-driven, but the contribution of private consumption has been growing due to high wage increases and low inflation. 



\section{The Nordic and international economy}

\subsection{Global developments}

Global economic activity has broadly gained momentum, and the recovery is expected to strengthen. Improved consumer and business confidence suggests that private consumption and corporate investments will continue to rise. Economic growth is being maintained, particularly in emerging countries, and is increasing in industrial countries.

The positive economic development of the United States continues. New industrial orders are increasing, and unemployment continues to decline. The Federal Reserve is continuing the normalisation of monetary policy, which is reflected in a rise in shortterm market rates. At the same time, the US dollar has recently weakened against the euro. There is uncertainty relating to the economic policy of the US administration, and US businesses and consumers remain cautious about future economic development.

The economic outlook in continental Europe has become more optimistic this year. Business and consumer confidence is high. Growth figures reported for this year are strong, and the growth is broader than previously. Unemployment in the euro area has fallen to its lowest level in eight years. The European Central Bank has indicated that unconventional monetary policy measures will continue indefinitely, until inflation stabilises below, but close to, $2 \%$, and until economic growth in the euro area becomes more robust.

The debt crisis in the euro area seems to be behind us. Most crisis countries have left the economic adjustment programmes and Greece has finally returned to economic growth. Concern is mainly caused by risks relating to the balance sheets of some European banks. During this year, the euro has strengthened against the other main currencies, reflecting the positive outlook of the euro area. However, in the longer term, the euro is likely to weaken against the US dollar, reflecting differences in monetary policy. 
The outlook of the Russian economy is largely dependent on developments in the energy sector. The rise in crude oil prices early in the year accelerated economic growth. The rouble has made gains against the US dollar following the rise in oil prices from the rock bottom seen in early 2016, but this trend appears to have been reversed recently due to greater fluctuation in prices. The growth potential of the Russian economy is weakened by the need for major economic restructuring, so economic growth in Russia will remain subdued in the next few years.

The first months of 2017 were a strong period for the Chinese economy, but the outlook of slowed growth for the coming years remains unchanged. Economic growth has been maintained by expansionary fiscal policy, as China has set an ambitious target for total output by the end of this decade. The transition of the Chinese economy from an export-driven to a consumption-driven model is slowing economic growth, which increases the risks arising from the considerable debt burden in the economy.

World trade has also developed favourably since late 2016. Trade has been accelerated by emerging economies, but is likely to be fuelled further by higher growth in the euro area. In the next few years, world trade will grow at virtually the same rate as global output, but the rate of growth will be much slower than during the most intensive periods of globalisation in the past decade.

Forecasts and assessment of the current state of the global economy are surrounded by uncertainty. Some risks are less likely, but if they transpire the economic impact could be great. Conversely, risks could be highly likely but have a more modest, although broad based, impact on global economic development. Each risk should be viewed separately, with uncertainty about its economic impact.

One positive risk worth noting is the stronger economic growth than expected in advanced economies, particularly in Europe. There are more substantial signs of a recovery in growth and investments and the recovery is broader than in the past.

US monetary policy normalisation may widen interest rate spreads between key economies and strengthen the dollar against the other main currencies over the longer term. Normalisation may have spillover effects on the global economy, as was the case a few years ago in conjunction with the "taper tantrum" episode. The risks are particularly related to the weakening of currencies of developing countries with external debt, which would reduce their debt-servicing capacity.

The heavy leverage of Chinese enterprises and, more broadly, the overall level of debt in the economy is a key risk in the global economy. When economic growth slows, the risks arising from indebtedness will increase, despite China also having sizeable 
buffers. The growing risk was reflected in the downgrading of China's credit rating in March 2017, the first downgrade in 30 years.

Measures relating to the trade policies of large countries, such as the looming threat of protectionism, pose a risk to the overall positive view of world trade growth. The Nordic economies are more export-oriented than most advanced economies, so greater protectionism would result in costlier, more difficult, and probably also smaller exports. Free trade is not just about tariffs - removal of other barriers to trade is equally important.

\subsection{Developments in the Nordic countries}

The Nordic countries are in different phases of the business cycle. Danish GDP growth is broad and is expected to reach the highest pace since 2006, with growth rates estimated at $2 \%$ this year. The largest contributions to growth are expected to come from private consumption and exports, while investments will become a more significant contributor in 2018 because of greater investment needs relating to higher capacity utilisation.

The Finnish economy is in a phase of rapid growth. In 2017 the rate of economic growth is expected to easily outperform that of 2016, after which the projected growth rate will slow to a level of around $2 \%$. Private consumption and, to some extent, growth in investment demand will slow, but exports will pick up. Improving global demand and business cost competitiveness will boost prospects for exports. Household consumption demand will be hampered by subdued purchasing power. Investment growth will be held back by a slowdown in the rate of housing construction but, at the same time, accelerated by major investment projects.

Employment activity level in the Swedish economy is high, and unemployment is decreasing. GDP is expected to grow by $3.1 \%$ in 2017 . The government's welfare initiatives, together with household consumption and investments, are helping maintain strong growth. Resource utilisation is estimated to be higher than normal in 2017, and is expected to rise further in 2018.

The cyclical downturn in Norway following the oil price drop three years ago has come to an end. Targeted fiscal policy, along with low interest rates and a distinct improvement in competitiveness, has served to promote growth and reduce unemployment. Household demand and mainland investments are rising. The fall in 
petroleum investments is gradually reversing. Higher household purchasing power and stronger demand for Norwegian exports will spur the recovery. Mainland GDP growth is projected to exceed trend next year.

The Icelandic economy is growing strongly, with GDP growth of more than $7 \%$ in 2016, and growth is expected to be $5-6 \%$ this year. The growth is export driven, but the contribution of private consumption has increased due to high wage increases and low inflation. Tourism is the largest export sector by far, but there are signs that the increase in tourism is slowing, and to a more sustainable level. Investment growth is slowing despite large increases in residential investment. A labour market under pressure is being increasingly supported by foreign labour. Despite pressures, inflation has remained low.

\subsection{Importance of trade}

As open, advanced economies, Nordic countries are reliant on global trade, reflected not only in the orientation of exports but also in the high level of integration in global value chains. Distinctive features of the trade profile in the Nordic countries are that goods exports exceed service exports, except for Iceland, and that exports are concentrated in certain industries or products. In Norway, most exports involve oil, in Finland paper, and in Iceland tourism, while Sweden and Denmark show a more diversified export profile. The importance of diversifying trade in high value-added products will be underlined in the future economic landscape.

Nordic countries follow similar trends regarding value-added trade. In all Nordic countries apart from Norway, the foreign value-added content of exports increased between 2008 and 2011, and accounts for one-third of exports. The value-added content of Norwegian exports is on a par with the other countries after controlling for oil and gas. Another similarity is the high service content of exports in value-added terms. In all Nordic countries, the value-added exports of services exceed those of gross exports of services with high domestic value-added content.

Open markets, trade and cross-border investments play an important role in the variety of goods and services available to households and businesses and for productivity growth. Cross-border activities bring in new ideas and help domestic economies remain in touch with global innovations. Open markets and trade also enable economies of scale and increase competition, which encourages the use of new, 
more efficient technology. These factors play a more important role for smaller economies, like those of the Nordic countries, than for bigger ones.

\section{$1.4 \quad$ Public finances}

In Denmark, fiscal policy is gradually being tightened to reduce the risk of overheating. The government is, for example, planning to reduce growth in public consumption in the coming years, which will dampen the capacity pressure. Overall, the planned consolidation of fiscal policy, together with a continuous reform agenda, will help maintain and extend a continued balanced upturn in the economy. Reforms that increase labour supply and free up new resources will also make it possible to allocate new funds to high-priority areas without increasing economic pressures. Fiscal policy has been gradually normalised in recent years, after a period during the crisis where public consumption and investment expenditures increased to high levels compared to historical averages. The consolidation means that fiscal policy in recent years has dampened an increase in demand relative to the lenient level during the crisis.

In Finland, the long-awaited economic growth is also improving the state of general government finances. Tax revenue is increasing and the decline in unemployment will reduce unemployment expenditure. However, the economic rebound does not eliminate the structural factors weakening general government finances, the most important of which is the ageing population, which increases pension, care and nursing expenditure, and thereby slows improvements in general government finances. Despite the economic recovery, general government expenditure clearly exceeds revenue.

The Swedish Government will continue to pursue a responsible fiscal policy. Refugee-related expenditure is expected to peak in 2017, and then decline. Despite this cost increase, public sector finances are projected to show surpluses amounting to nearly $1 \%$ or more of GDP each year of the forecast period. The cyclically adjusted balance as a proportion of GDP is expected to remain broadly stable, and the debt to GDP ratio will fall.

Fiscal policy in Norway has been expansionary for several years, to support economic activity after the fall in oil prices in 2014. The outlook for the Norwegian economy now suggests a fiscal policy normalisation in 2018 , i.e. a neutral fiscal policy stance as reflected in the Government's budget proposal. Petroleum revenue spending is estimated to 
correspond to $2.9 \%$ of the capital of the Government Pension Fund Global, the same level as for the current year, and below the expected real return of the fund.

Iceland has been able to reduce the central government debt-to-GDP ratio over the years with high primary balance surpluses. The fiscal budget remains in surplus, with low and falling public total debt. Capital controls introduced at the height of the 2008 crisis have been lifted. Some restrictions on capital mobility remain but they are minimal and solely regard the remaining offshore króna assets and measures to temper carry trade. Furthermore, prudent measures to temper carry trade in the form of new foreign currency inflows were introduced in June 2016.

Table 1: Central macroeconomic variables

\begin{tabular}{|c|c|c|c|c|c|}
\hline & 2014 & 2015 & 2016 & 2017 & 2018 \\
\hline \multicolumn{6}{|l|}{ GDP growth, \% } \\
\hline Sweden & 2.6 & 4.5 & $3 \cdot 3$ & 3.1 & 2.5 \\
\hline Iceland & 1.9 & 4.1 & 7.4 & 6.0 & $3 \cdot 3$ \\
\hline Finland & -0.6 & 0.0 & 1.9 & 2.9 & 2.1 \\
\hline Mainland Norway & & & 1.0 & 2.0 & 2.5 \\
\hline Denmark & 1.7 & 1.6 & 1.7 & 2.0 & 1.8 \\
\hline \multicolumn{6}{|l|}{ Inflation, \% } \\
\hline Sweden & -0.2 & 0.0 & 1.0 & 1.6 & 1.7 \\
\hline Iceland & 2.0 & 1.6 & 1.7 & 1.9 & 2.7 \\
\hline Finland & 1.0 & -0.2 & 0.4 & 0.9 & 1.5 \\
\hline Norway & & & 3.6 & 1.9 & 1.6 \\
\hline Denmark & 0.6 & 0.5 & 0.3 & 1.1 & 1.5 \\
\hline \multicolumn{6}{|c|}{ Unemployment (LFS), \%* } \\
\hline Sweden & 7.9 & 7.4 & 6.9 & 6.6 & 5.9 \\
\hline Iceland & 5.0 & 4.0 & 3.0 & 2.6 & 2.9 \\
\hline Finland & 8.7 & 9.4 & 8.8 & 8.6 & 8.1 \\
\hline Norway & & & 4.7 & $4 \cdot 3$ & 4.0 \\
\hline Denmark & 4.6 & 4.2 & 3.8 & 3.8 & 3.7 \\
\hline \multicolumn{6}{|c|}{ Current account balance, percentage of GDP } \\
\hline \multicolumn{6}{|c|}{ Sweden } \\
\hline Iceland & & & 8.0 & 5.8 & 5.0 \\
\hline Finland & -1.3 & -0.6 & -1.1 & -1.3 & -1.4 \\
\hline \multicolumn{6}{|l|}{ Norway } \\
\hline Denmark & 8.9 & 9.2 & 7.9 & 8.2 & 7.9 \\
\hline
\end{tabular}

Note: * Registered unemployment in Denmark. 


\section{Denmark}

\subsection{Economic outlook}

The upturn in the Danish economy has continued in 2017. GDP has grown rapidly, increasing by up to $0.75 \%$ each quarter since the beginning of 2016 . Simultaneously, the outlook for economic growth in neighbouring countries has also become brighter. GDP growth is expected to reach the highest pace since 2006, with growth rates estimated at $2 \%$ this year and $1.8 \%$ next year.

The economic progress is broad-based. The greatest contributions to growth are expected to come from private consumption and exports, while investments will become a more significant contributor in 2018 , as investment needs increase due to higher capacity utilisation.

Private consumption - a key driver of growth for the Danish economy - has increased strongly since 2014. Higher private consumption should be viewed in the context of employment gains and rising incomes, higher housing wealth, and generally positive expectations.

Furthermore, subdued price increases ensure solid increases in real wages, although nominal wage rises are moderate. The option of tax-free reimbursements of early retirement contributions in 2018 will also boost private consumption.

Exports are expected to continue to grow at a fast pace, with growth in 2017 projected to be the highest since 2011. This is based on stronger demand from export markets. The upturn in the euro area appears to have firmed, due to factors such as declining unemployment. In general, there is evidence of a strengthened global economy, which is reflected in increasing world trade. This development benefits Danish exporters as well, and exports rose sharply during the second half of 2016. Overall, Danish firms appear to be competitive on global markets, particularly industrial firms, and industrial exports are expected to grow strongly in 2017. The pace of growth in 2018 is projected to slow somewhat, a result of slower export market growth.

Rising capacity utilisation is expected to increase the need for new productive capital over the coming years, and private investment is expected to increase over the 
forecast period. Housing investment is already growing quite strongly, because of new construction activity fuelled by rising housing prices. Construction of new housing is expected to remain high in the forecast period.

Public demand is forecast to increase at a relatively subdued rate in line with the government's priorities. Also, at the current stage of the economic cycle, where firms report increasing labour shortages, public demand should be planned in order to diminish capacity pressures. Fiscal policy is dampening demand in 2017-2018, contributing to a sustainable upturn.

The positive developments have brought the Danish economy back to a neutral business cycle stance. At present there are no signs of price and wage pressures, but capacity pressures are increasing, particularly in the cyclically sensitive construction sector.

Since 2013 , employment has risen by about 150,000 , and last year alone almost 50,000 persons found a job. This employment trend is expected to continue, so that total employment will reach nearly 3 million by the end of the forecast period, approaching its highest-ever level.

Increases in employment over the past years imply that there are fewer available resources in the labour market. Unemployment is already low and is expected to remain low during the forecast period, so a sustainable increase in employment is conditional upon a larger labour force.

The labour force has already grown significantly in recent years and is currently estimated to be at an all-time high. This largely reflects previous reforms that in the coming years will contribute to further sustainable employment growth, particularly the 2006 Welfare Reform and the 2011 Early Retirement Reform. Structural employment is estimated to increase by about 50,000 persons in 2017 and 2018.

Foreign labour has also added to the labour force to a large extent. Over the past four-and-a-half years, the number of foreign citizens who have found employment in Denmark has increased by about 65,000 . In total, foreign wage earners in Denmark amount to roughly 240,000 . The increase corresponds to more than $40 \%$ of the total increase in employment since 2013. Many foreign employees work in the cleaning industry, in hotels and restaurants, and in farming. There has also been a relatively large increase in the construction sector.

The overall employment increase from 2013 to 2018 is expected to be roughly the same size as in previous upturns but, over the same period, the increase in the labour force is projected to exceed previous experiences. 
It is the expected expansion of the labour force during the forecast period that makes a sustainable increase in employment possible. Employment is expected to exceed the structural level in 2018 , but only slightly. In comparison, employment exceeded the structural level by 52,000 persons in 1987 and 86,000 in 2008 .

The experience from previous upturns is that a situation where actual employment exceeds structural employment by a large margin may arise relatively quickly. Two years before the business cycle peaks in 1987 and 2008, actual employment was close to its structural level.

In some areas of the labour market, there are signs of mounting capacity pressures. This is particularly evident in construction, where firms increasingly report labour shortages as a constraint to production. This implies that an increasing number of firms may have to turn down new orders.

The premises for stable growth are judged to be present, but uncertainty remains regarding the economic development, both domestically and abroad.

In Denmark, demand especially from private consumption has risen strongly during the past 18 months. However, consumption and investment ratios are still low in a historical perspective. This implies a potential for an even stronger increase in private demand. If the pace of growth accelerates, and the increased demand is met by higher production, GDP might exceed forecasts.

However, labour shortages could dampen the upturn in the Danish economy. There is a risk that production might exceed what is compatible with stable price and wage developments. In the longer term, this could trigger accelerating prices and wages and ultimately cause overheating of the labour market, as happened in 2006-2007.

\subsection{Public finances}

In the current situation with high employment and low unemployment, it is appropriate that fiscal policy is gradually tightened to reduce the risk of overheating. The Danish Government is planning a subdued growth in public consumption in the coming years, which will dampen the capacity pressure. Overall, the planned consolidation of fiscal policy in the coming years, together with a continuous reform agenda, will help maintain and extend a continued balanced upturn in the economy. Reforms that increase labour supply and free up new resources will also make it possible to allocate new funds to high-priority areas without increasing economic pressures. 
Fiscal policy has been gradually normalised in recent years after a period during the crisis where public consumption and investment expenditures were increased to high levels compared to historical averages. The consolidation means that fiscal policy in recent years has had a dampening effect on demand relative to the lenient fiscal policy during the crisis.

In 2018 , the structural budget balance is estimated at $-0.3 \%$ of GDP, and the distance to the maximum allowed structural deficit in the budget law is gradually increasing. This is in line with the targets in the government's 2025 plan (Growth and Prosperity 2025) and the cyclical improvement. The government's fiscal targets presented in the 2025 plan include a target of structural deficit of $0.1 \%$ of GDP in 2020 and a target of structural balance in 2025. With technical assumptions, the presumed fiscal policy since 2014 contributes to dampening the GDP level by approximately $1 \%$ in 2017 and 2018.

It is presumed that public consumption will grow by $0.5 \%$ in 2018 . In addition to a basic real growth of $0.3 \%$, the public expenditure growth also reflects a contribution from reserves on the budget proposal that can be allocated to other initiatives, such as improving the safety and security of the Danish population.

The fiscal deficit in 2016 was $0.6 \%$ of GDP. It is estimated that the fiscal deficit will amount to $1.4 \%$ of GDP in 2017 and $1.2 \%$ in 2018. The weakening of the public budget balance from 2016 to $2017-2018$ is specifically due to the volatile revenues from pension yield taxation, which is assumed to decrease by approximately 1.5\% of GDP from 2016 to 2018. This should be seen in the light of the expected normalisation of long-term interest rate levels in the coming years, after several years with unusually low interest rates. When the fiscal deficit is adjusted for the volatile revenue from the pension yield taxation, the deficit is reduced by approximately $0.5 \%$ of GDP from 2016 to 2018 . This is primarily due to the progress in the Danish economy.

In 2018, the fiscal deficit will be affected by a refund of early retirement contributions, estimated at DKK 5 billion (or $0.25 \%$ of GDP). The refund is a consequence of the agreement on more years on the labour market. The agreement makes it possible for people to receive a tax-free refund of early retirement contribution payments in 2018, if they renounce their right to early retirement.

In 2018, the net public debt is estimated to be at a continued low level of approximately $7 \%$ of GDP, while the EMU debt is estimated at approximately $35 \%$ of GDP. Consequently, the public debt in Denmark is substantially under the limit of $60 \%$ of GDP stipulated in the Stability and Growth Pact. 
Along with the Budget proposal, the Danish government has presented plans for proposed tax cuts (Job Reform Phase II) and a number of initiatives targeting business and entrepreneurship that will make it easier to run a business in Denmark.

The planned fiscal consolidation in the coming years, together with an ongoing reform agenda, will help to maintain and prolong a balanced economic upswing.

Table 2: Key figures for the Danish economy

\begin{tabular}{|c|c|c|c|c|c|c|}
\hline & $\begin{array}{r}2016 \\
\text { DKK bn. }\end{array}$ & 2014 & 2015 & 2016 & 2017 & 2018 \\
\hline Private consumption & 981 & 0.5 & 1.9 & 2.1 & 2.4 & 2.4 \\
\hline Public consumption & 525 & 1.2 & 0.6 & 0.4 & 0.8 & 0.5 \\
\hline Fixed business investments & 246 & 0.1 & 4.1 & 4.4 & 3.0 & $4 \cdot 3$ \\
\hline Stock building (percentage of GDP) & 2.6 & 0.2 & -0.3 & -0.2 & -0.1 & 0.0 \\
\hline Total domestic demand & 1,926 & 1.5 & 1.3 & 2.1 & 1.8 & 2.2 \\
\hline Exports & 1,102 & 3.6 & 1.8 & 2.5 & 3.8 & 2.9 \\
\hline Total demand & 3,028 & 2.3 & 1.5 & 2.3 & 2.5 & 2.5 \\
\hline Imports & 963 & 3.6 & 1.3 & 3.5 & 3.7 & 3.8 \\
\hline GDP & 2,065 & 1.7 & 1.6 & 1.7 & 2.0 & 1.8 \\
\hline Employment (1,000 persons) & & 2,794 & 2,829 & 2,877 & 2,921 & 2,946 \\
\hline Gross unemployment (percentage of labour force) & & 4.6 & 4.2 & 3.8 & 3.8 & 3.7 \\
\hline Consumer price index (\%) & & 0.6 & 0.5 & 0.3 & 1.1 & 1.5 \\
\hline Hourly wage (\%) & & 1.2 & 1.9 & 2.3 & 2.5 & 2.8 \\
\hline Effective exchange rate $(1980=100)$ & & $103 \cdot 3$ & 99.2 & 100.8 & 102.0 & 102.9 \\
\hline Terms of trade (goods) & & 1.0 & 1.7 & 3.1 & -0.1 & 0.4 \\
\hline Current account (percentage of GDP) & & 8.9 & 9.2 & 7.9 & 8.2 & 7.9 \\
\hline 3-month money market interest rate $(\%)$ & & 0.3 & -0.1 & -0.1 & $-0,2$ & -0.1 \\
\hline
\end{tabular}

Source: Statistics Denmark and the Danish Ministry of Finance. 



\section{Finland}

\subsection{Economic outlook}

The Finnish economy is in a phase of rapid growth. In 2017 the rate of economic growth is expected to outperform that of 2016, after which the projected rate will slow to around $2 \%$. Over the next few years, economic activity will be driven by both domestic and foreign demand, but the patterns show clear differences. Private consumption and, to some extent, growth in investment demand will slow, but exports will pick up. Improving global demand and business cost competitiveness will boost prospects for exports. Household consumption demand will be hampered by subdued purchasing power. Investment growth will be held back by a slowdown in housing construction, but accelerated by major production-related investment projects.

Finland's foreign trade has picked up since the start of the year. This reinvigoration can be mainly attributed to the positive economic development in Finland's export markets early in the year. The rapid increase in exports is mainly due to the rebound of demand in the export markets. Growth was seen across the board in all traditionally significant export products, such as paper and mechanical engineering and chemical industry products.

In 2017, export increases will outperform growth in world trade, and the long period of lost market shares will end. Exports will grow, driven by export demand, in 2018 and 2019, although at a slower rate than this year. Exports will continue to be mainly driven by goods exports, which will require imported inputs. In addition to demand for imported inputs, imports will also increase in other sectors, such as wholesale and retail trade.

Despite the stronger growth in exports, the current account will remain in deficit throughout the forecast period. This is mainly due to the deficit in the service account and the secondary income account, and the greater increase in import prices than export prices.

Improved purchasing power and employment are maintaining the growth of private consumption. Increases in labour input and the earnings level will accelerate the increase in the sum of wages and salaries. Social transfers will continue to grow, despite the 
gradually falling unemployment rate. Increases in current transfers will be maintained by rises in pensions, as pensions account for almost half of current transfers. Property income will also continue to increase reasonably rapidly as the economy rebounds.

However, accelerating inflation will slow the increase in household disposable real income, decelerating the growth in private consumption. The household savings rate will remain in negative territory over the forecast horizon, despite the slowdown of consumption. Low interest rates and ready access to loans have increased borrowing. Long-standing low interest rates coupled with loan repayment holidays have further fuelled increasing household debt.

The investment focus is shifting from residential housing construction to, particularly, industrial machinery and equipment and R\&D investment by enterprises. The negative real interest rate and easy access to financing will bolster investment throughout the forecast horizon. Private investment increases during the outlook period will average $4.5 \%$ per year. Increased investment will raise GDP growth by an average of almost 1 percentage point a year.

The number of new residential building projects started has risen to a record level. Construction of apartment blocks has never been at such a high level since records began. In addition to investors, residential building construction is currently supported by consumer interest in buying residential property. Construction investment is expected to pick up again towards the end of the forecast horizon, as can be seen in the major projects scheduled for 2018 and 2019.

Industrial capacity utilisation rates have risen, especially in the forest industry but also in the metal industry, and these create the need to add new capacity. Once launched, the major construction projects will also result in a considerable increase in investment in machinery and equipment in the next few years.

Research and development (R\&D) investment is forecast to gradually show a distinct upturn, but the EK investment survey still shows a grim outlook for industrial R\&D investment for the current year. On a positive note, however, expectations for the technology industry, the most important sector for R\&D investment, have already improved, and total investment is increasing.

The broad-based and rapid strengthening of economic activity increased employment in early 2017. The number of job vacancies has remained very high, and the seasonally adjusted figure is more than 40,000 vacant positions. 
There was virtually no decrease in unemployment in early 2017 and the unemployment rate remained at $8.7 \%$. The standstill in the decline of the unemployment rate is at least partly due to measures to activate the disguised unemployed and other persons outside the labour force to become jobseekers, which is normal in periods of economic rebound. The pickup in economic growth will push unemployment back onto a downward trajectory towards the end of the forecast horizon.

The continuing reasonably rapid growth of GDP in 2018 and 2019 will have a positive effect on employment, and the number of unemployed persons will decrease. The forecast assumes that wage and salary increases will remain moderate and support employment during the forecast period.

The supply of labour will not have a major restricting effect on the increase in employment during the forecast period, as the combined total number of unemployed and disguised unemployed remains very large, almost 400,000 persons. Nevertheless, a shortage of labour can already be discerned in certain occupational groups.

In 2017, wage development will mainly be determined by the Competitiveness Pact concluded by the social partners, which led to no increases in negotiated wages.

Wage negotiations for 2018 will be industry-specific. Wages are expected to continue to rise moderately, considerably slower than the average rate of increase in the 2000s, which is well in line with the high unemployment rate.

The inflation forecast for 2017 is $0.9 \%$. Driven by the increase in the price of crude oil last year, the energy sub-item had a major effect on inflation. Service prices are projected to rise by around 1.6\% this year, much slower than 2016. Contributing factors include last year's wage and salary settlements and the slowing of the increase in rent rates.

Inflation is expected to increase in 2018 and 2019 to $1.5 \%$ as economic growth continues. Prices will rise more broadly than this year across commodity groups, but the rise in service prices will continue to have the greatest impact on overall inflation. The increasing price of oil, the strengthening US dollar and the low, yet rising, interest rate level are expected to accelerate inflation during the outlook period.

Overall, the economic outlook for 2017-2019 is more positive than in previous years. However, the general conditions for economic growth and the structures determining these have not changed to an extent that would increase the growth potential of the economy. 
In the medium term, 2020-2021, economic growth is projected to return to the level of potential output increases, i.e. a little over $1 \%$. The slowness of potential growth is due to structural factors in the economy. On the one hand, the shrinking working-age population and the persistence of relatively high structural unemployment maintain zero growth in labour input, despite the more active participation of older age cohorts in the labour market. On the other hand, productivity growth has slowed as the output of high-productivity sectors has declined significantly and the overall structure of the economy has shifted towards services. In addition, the low investment rate that has continued for several years has slowed the generation of new productive capital. However, the rise in investment rates that started in 2016 is gradually beginning to improve the situation.

The domestic risks are related to confidence and the labour market. As there will only be slight increases in household purchasing power, greater consumption will be based on strong confidence that could be quickly eroded. The forecast for wages and salaries assumes that collectively agreed pay rises will be very modest in 2018 and 2019. Pay rises for 2018 will be negotiated by sector, which increases the uncertainty of the pay forecast. Pay rises that are higher than anticipated may slow increases in exports and employment. There is uncertainty regarding investment, arising from potential delays in planned major projects.

\subsection{Public finances}

The long-awaited economic growth is also improving the state of general government finances. Tax revenue is increasing and the decline in unemployment will reduce unemployment expenditure. However, the economic rebound does not eliminate the structural factors weakening general government finances, the most important of which is the ageing population, which increases pension, care and nursing expenditure, and thereby slows improvements in general government finances. Despite the economic recovery, general government expenditure clearly exceeds revenue.

General government deficit has decreased gradually in recent years. General government finances have been strengthened by the fiscal adjustment decisions taken by the Government and the economic growth triggered last year. The deficit will also continue to shrink in the coming years. General government debt has increased 
significantly in the past eight years but, over the next few years, the rate of debt accrual will slow and the debt-to-GDP ratio will fall.

The problems of general government finances are structural. Despite the positive point in the cycle, general government finances will still show a deficit. In addition, due to the ageing of the population, a major imbalance between revenue and expenditure will persist in general government finances over the long term. The budgetary position needs to show a clear surplus in the early 2020 s if general government finances are to move onto a sustainable trajectory in the long term, and if pension, care and nursing expenditure can be covered without measures to strengthen general government finances or increase debt.

The central government deficit fell last year. Central government revenues increased, particularly through increased tax revenue, and expenditure increase remained moderate. This trend in central government finances will continue in the next few years. The local government deficit also fell in 2016, and this trend will continue in 2017. The expenditure pressure caused by the growing service needs of an ageing population will be transferred to counties, as the health, social services and regional government reform takes effect. This will ease upward pressure on local government expenditure. The combined deficit of central, local and, later, county government is projected to be considerable in the early zozos.

The expenditure rate, i.e. the ratio of expenditure to GDP, rose to its highest level this millennium in 2014, since when it has been falling steadily due to measures that include adjustment. The tax ratio, i.e. the ratio of taxes and tax-like payments to GDP, will decrease this year for reasons including the Competitiveness Pact changes to payment criteria and tax cuts. In the coming years, the tax ratio will also decrease to some extent, because many tax bases are growing more slowly than GDP.

Fiscal policy at general government level is somewhat expansionary in 2017. The expansionary effects of the Competitiveness Pact and associated Government decisions on tax cuts amount to around EUR 1.2 billion. Approximately EUR 750 million of the Government's fiscal adjustment measures are targeted at central government. Fiscal policy will tighten because of local government adjustment measures and the pension insurance contribution hike in the private sector. 
The Competitiveness Pact is likely to result in a drop in the tax ratio in 2017 by approximately $1 \%$ point from last year's figure of over $44 \%$ of GDP. The tax ratio will continue to fall over the next few years, as the most important tax bases, including the sum of wages and salaries, and private consumption, will increase more slowly than GDP. The expenditure rate began to edge down in 2015, and the same trend will continue in the coming years, in response to savings measures and reduced cyclical expenditure.

The fiscal stance can also be examined on the basis of changes in the structural balance assessed using the common EU methodology. An examination based on changes in the structural balance does not necessarily give the same picture as one focused on individual revenue and expenditure measures. For example, increasing agerelated expenditure has the effect of weakening the structural deficit over the outlook period, even in the absence of any decisions to increase expenditure.

The structural deficit is estimated to increase clearly this year and next, while fiscal policy can be regarded as expansionary over these years. The structural deficit will increase, as the output gap is closing rapidly. From 2019 onwards, fiscal policy can be regarded as more or less neutral, as the structural deficit is anticipated to remain at around $1 \%$ of GDP.

General government debt rose by EUR 2.7 billion last year, much less than for several years, and the debt-to-GDP ratio took a downturn. However, the debt ratio clearly exceeded the $60 \%$ reference value. In the next few years, nominal debt will increase, but the debt ratio will continue to fall and may even go below the $60 \%$ threshold in the medium term. The debt ratio trend is partly explained by the value of GDP being currently projected to be more than EUR 10 billion higher in 2021 than estimated this spring. General government debt-to-GDP ratio decreased by 0.5 percentage points in 2016. 
Table 3: Key figures for the Finnish economy

\begin{tabular}{|c|c|c|c|c|c|c|c|}
\hline & 2016 & 2014 & 2015 & 2016 & 2017 & 2018 & 2019 \\
\hline & EUR bn. & \multicolumn{6}{|c|}{ Percentage change unless stated otherwise } \\
\hline GDP at market prices & 2016 & -0.6 & 0.0 & 1.9 & 2.9 & 2.1 & 1.8 \\
\hline Imports & 79 & -1.3 & 3.2 & 4.4 & 2.9 & 2.6 & 3.1 \\
\hline Total supply & 294 & -0.8 & 0.9 & 2.6 & 2.9 & 2.2 & 2.2 \\
\hline Exports & 76 & -2.7 & 0.8 & 1.3 & 4.7 & 3.7 & 4.1 \\
\hline Consumption & 171 & 0.4 & 1.1 & 1.6 & 1.6 & 1.2 & 1.0 \\
\hline private & 119 & 0.8 & 1.7 & 1.8 & 2.4 & 1.4 & 1.2 \\
\hline public & 52 & -0.5 & 0.0 & 1.2 & -0.3 & 0.8 & 0.4 \\
\hline Investment & 46 & -2.6 & 0.7 & 7.2 & 4.7 & 3.7 & $3 \cdot 5$ \\
\hline private & 38 & -3.4 & 2.2 & 7.9 & $5 \cdot 5$ & 4.0 & 4.1 \\
\hline public & 9 & 0.9 & -5.2 & 3.9 & 1.0 & 2.1 & 0.9 \\
\hline \multicolumn{8}{|l|}{ EUR bn. } \\
\hline GDP & & 205 & 210 & 216 & 224 & 232 & 241 \\
\hline Current account & & -2.6 & -1.2 & -2.3 & -3.0 & -3.2 & -3.3 \\
\hline \multicolumn{8}{|l|}{ Percentage change } \\
\hline Services, change in volume & & -0.4 & 0.2 & 1.3 & 2.0 & 1.5 & 1.4 \\
\hline Industry, change in volume & & -0.2 & -1.6 & 1.1 & 6.8 & 2.8 & 3.0 \\
\hline Labour productivity, change & & 0.1 & 0.1 & 1.2 & 2.1 & 1.3 & 1.5 \\
\hline Employed labour force, change & & -0.4 & -0.4 & 0.5 & 0.7 & 0.8 & 0.5 \\
\hline Employment rate & & 68.3 & 68.1 & 68.7 & 69.4 & 70.1 & 70.5 \\
\hline Unemployment rate & & 8.7 & 9.4 & 8.8 & 8.6 & 8.1 & 7.8 \\
\hline Consumer price index & & 1.0 & -0.2 & 0.4 & 0.9 & 1.5 & 1.5 \\
\hline Index of wage and salary earnings & & 1.4 & 1.4 & 1.1 & 0.3 & 1.4 & 1.6 \\
\hline Short-term interest rates (3-month Euribor) & & 0.2 & 0.0 & -0.3 & -0.3 & -0.2 & 0.0 \\
\hline Long-term interest rates (10-year govt. bonds) & & 1.5 & 0.7 & 0.4 & 0.5 & 0.9 & 1.4 \\
\hline \multicolumn{8}{|l|}{ Percentage of GDP } \\
\hline Tax ratio & & 43.9 & 44.0 & 44.1 & 43.2 & 42.2 & 41.8 \\
\hline General government net lending & & -3.2 & -2.7 & -1.8 & -1.2 & -1.4 & -1.0 \\
\hline Central government net lending & & -3.8 & -3.0 & -2.7 & -2.3 & -2.0 & -1.4 \\
\hline General government gross debt & & 60.2 & 63.6 & 63.1 & 62.5 & 61.9 & 61.1 \\
\hline Central government debt & & 46.3 & 47.6 & 47.5 & 47.7 & 47.5 & 46.9 \\
\hline General government expenditure & & 58.1 & 56.9 & 55.8 & 54.1 & 53.1 & 52.2 \\
\hline Current account & & -1.3 & -0.6 & -1.1 & -1.3 & -1.4 & -1.4 \\
\hline
\end{tabular}

Source: Statistics Finland and the Finnish Ministry of Finance.

The general government primary balance in 2016 showed a deficit of $0.7 \%$ of GDP. This had the effect of increasing debt by 0.7 percentage points. Interest outlays increased the debt ratio by 1.1 percentage points. When the level of debt is compared with GDP, GDP value growth has the effect of lowering the debt ratio. In 2016, the value of GDP increased by $2.9 \%$, which slowed debt growth by 1.8 percentage points. 
The Government has set the target of increasing the employment rate to $72 \%$ and the number of employed persons by 110,000 during its term in office. The labour market situation will improve in the next few years but, in light of the forecast, the employment target is unlikely to be met.

The Government aims to strengthen conditions for employment and economic growth through structural reforms and taxation measures. The supply of labour will be strengthened through measures including eliminating incentive traps, increasing labour mobility, reforming the unemployment security system and public employment services, and ensuring that employee income taxes do not increase. The Competitiveness Pact that came into effect this year will, in turn, improve the competitiveness of Finnish enterprises and increase the demand for labour. However, the rise in employment enabled by the Pact requires that the competitive advantage gained through the Pact will be managed in the wage and salary settlements of the coming years. 


\section{Iceland}

\subsection{Economic outlook}

The Icelandic economy grew by $7.4 \%$ in 2016 , the fastest rate of growth in the OECD countries. Further robust growth, $5-6 \%$, is projected for 2017 . Unlike in previous upswings, the internal and external balance of the economy appears solid. Iceland is running a current account surplus, which amounted to almost $8 \%$ of GDP in 2016 . Net capital outflows relating to the current account surplus, together with the settlement of the failed financial institutions' estates and their stability contributions, have markedly improved Iceland's net international investment position. Furthermore, inflation has remained below the Central Bank's target of 2.5\% for nearly four years.

Investment has grown rapidly in recent years. In 2016, it grew by almost $23 \%$ yearon-year, following nearly $17 \%$ growth in each of the two preceding years. The main driver of the increase is business investment, which has grown by an average of almost $25 \%$ per year in the past three years. The increase has been particularly notable in sectors relating to transport and tourism. Residential investment has also picked up strongly, growing by over a third in 2016. The forecast is for a marked slowdown in investment growth this year, but investments will remain robust.

Construction of residential properties fell dramatically after the financial crisis. Demand for housing picked up after the economy rebounded, but supply of housing has reacted slowly to the growing demand. In addition, the inflow of foreign workers and the boom in tourism has further increased demand for housing. As a result, housing prices have risen rapidly, with the year-on-year increase over $20 \%$ in mid-2017.

The exchange rate has appreciated rather rapidly in the past couple of years. The appreciation is largely due to increased tourism, considerably better terms of trade, and a substantial improvement in Iceland's external position. It therefore reflects the adjustment of the króna to a higher equilibrium real exchange rate rather than carry trade-related inflows.

Iceland has experienced a boom in tourism, with visitor numbers growing almost exponentially since the eruption of Eyjafjallajökull in 2010. The number of foreign 
visitors increased by almost $40 \%$ in 2016 , when 1.8 million tourists visited Iceland. The growth rate so far in 2017 is around $30 \%$ and 2.2-2.3 million visitors are expected this year. The surge in tourist numbers has boosted the economy, helping unwind some of the impacts of the financial crisis. New jobs have been created and foreign currency earnings have risen, while the boost to tax revenues has helped improve public finances. However, at current rates of expansion, tourism also brings many challenges with regard to the environment and overall infrastructure in Iceland.

The Icelandic labour market is quite flexible. Employment protection is low, companies can easily adjust their labour force, and labour-market needs are fulfilled by large variation in employment and migration flows. At present, the labour market conditions are tight, with very low unemployment and labour force participation nearing all-time highs. As a result, many firms consider themselves short-staffed. The labour shortage has largely been met with an inflow of foreign workers, thereby dampening overheating pressures as domestic firms meet their labour demand by importing labour rather than overbidding wages. Despite the inflow of workers, collective bargaining agreements have led to substantial wage increases in the past two years.

Despite rapidly increasing wages, inflation has remained low due to favourable external conditions and a substantial exchange rate appreciation. Purchasing power of households has increased markedly as a result. Unlike the expansion a decade ago, both households and firms have taken advantage of favourable economic conditions and paid down debt. Private sector debt was around $160 \%$ of GDP at the end of 2016, its lowest ratio since 2003 and substantially lower than the peak of over $350 \%$ of GDP in 2008.

The banking system is currently much smaller than before the financial crisis. The commercial banks' assets, which were more than nine times GDP in 2008, are now approximately 1.3 times GDP. The banks are well capitalised, with a combined capital ratio of the three main commercial banks of almost $28 \%$, well above the regulatory minimum. In addition to a strong capital position, the liquidity of the financial system is sound, and default is low as borrower positions are good. The banks are therefore well equipped to withstand possible adverse future shocks.

The economic environment is generally very favourable, but the ongoing expansion also brings important challenges for economic policy. There is an obvious risk of overheating, as the economy is growing rapidly and many firms are operating at full capacity. Furthermore, the growth in tourism creates externalities for the environment, 
the housing market and the overall infrastructure, and unsustainable wage increases threaten the economy's competitiveness.

\subsection{Public finances}

The National Budget for 2017 provides for a total balance surplus of ISK 28.5 billion, or $1.1 \%$ of GDP. The five-year fiscal strategy plan 2017-2022 provides for surplus over the whole period, with surplus of $1.6 \%$ of GDP in 2018 , to be followed by years with $1-1.5 \%$ of GDP.

Public debt is declining steadily over the strategy plan period, but interest costs are still a substantial burden. The ratio of general government debt to GDP has fallen rapidly in recent years. According to the debt provision in the law on public finances, ${ }^{1}$ gross debt is estimated to decline from $50 \%$ of GDP by the end of 2016 to approximately $35 \%$ by the end of 2019. Gross debt, as defined in the law, is total debt excluding pension liabilities and accounts payable/receivable, and deductions for currency and bank deposit assets, e.g. in CBI.

In accordance with recommendations from the IMF, the authorities have emphasised simplifying the tax system and improving work incentives by lowering marginal tax rates. From 1 January 2016, the first and second rates of personal income tax were lowered, to $37.13 \%$ and $38.35 \%$ respectively, while the third rate was kept at $46.25 \%$. A second phase of these reforms took effect in 2017 , lowering the bottom rate to $36.95 \%$ and abolishing the second rate.

Reforms of value-added tax (VAT) continue. In 2015, the gap between the standard rate and the reduced rate was narrowed by raising the reduced rate from $7 \%$ to $11 \%$ and lowering the standard rate from $25.5 \%$ to $24 \%$. Commodity tax was abolished at the same time. In January 2016, the VAT tax base was broadened substantially, as exemptions for passenger transport and tourism-related recreation were abolished. In 2017, occupational tax was increased from ISK 100300 per night. According to the fiscal strategy plan, tourism-related services will be moved from reduced VAT rate to standard rate in 2018. The standard rate will be lowered from $24 \%-22.5 \%$ at the same time.

${ }^{1}$ Total liabilities, excluding pension liabilities and accounts payable, minus currency and bank deposits assets, shall be lower than $30 \%$ of gross domestic product. 


\subsection{Lifting of capital controls}

In June 2015, the Icelandic authorities introduced a comprehensive strategy to liberalise the capital account. The strategy involved a three-point action plan:

- The problem created by the failed financial institutions' estates was solved in early 2016 when the winding-up of the failed banks was completed.

- A series of auctions by the Central Bank has reduced the amount of offshore króna assets, i.e. liquid ISK assets likely to seek exit from the domestic economy when capital controls are lifted, from its peak of above $40 \%$ of GDP to less than $4 \%$ of GDP.

- Capital controls on individual, businesses and pension funds were lifted in March, after being eased in two steps in October 2016 and January 2017.

Some restrictions on capital mobility remain, but they are minimal and affect few. They mainly consist of measures to prevent excessive capital inflows due to carry trading. The capital account liberalisation in March did not affect the remaining offshore króna assets, which remain in accounts subject to special restrictions.

The Central Bank adopted a capital flow management measure (CFM) in 2016. The CFM is intended to reduce the risk that could accompany excessive capital inflows and contribute to macroeconomic and financial stability by affecting the composition of foreign currency inflows. Under the measure, $40 \%$ of new inflow into bonds and highyield deposits are deposited at the Central Bank for a year at zero interest rates. The Icelandic Government does not view the CFM as an active long-term policy instrument, but rather as a third line of defence to supplement conventional macroeconomic policy and macroprudential tools if needed.

After the capital controls were lifted in March, Fitch and Standard \& Poor's raised Iceland's sovereign credit rating. Moody's noted that the elimination of capital controls is credit positive for the sovereign and the financial sector. 


\subsection{Brexit}

Like other Nordic countries, Iceland is dependent on international trade. Iceland's main trading partners are the US and UK, although aggregated Euro countries are the largest in gross and value-added terms. Iceland is concerned about the Brexit development, and is attempting to keep good relations with the British trading partners. Even though the UK's share of trade in goods has declined in recent years, its importance as service trading partner has increased, with the tourist sector blossoming. Emphasis has been placed on assessing the potential impacts of Brexit on the Icelandic economy. Working groups have been set up to evaluate possible effects and to propose actions to mitigate the effects. This work is ongoing, and no results or suggestions have been put forward so far. Discussions are underway between the EFTA countries and the UK to ensure "business as usual" after Brexit.

Table 4: Key figures for the Icelandic economy

\begin{tabular}{lcccc} 
& 2016 & 2017 & 2018 & \\
& & & & \\
Percentage change unless stated otherwise & & 5.2 & 3.4 \\
Private consumption & 6.9 & 6.9 & 1.3 & 1.2 \\
Public consumption & 1.5 & 1.8 & 4.0 & 2.7 \\
Gross fix capital formation & 22.7 & 9.8 & 4.1 & 3.4 \\
Exports of goods and services & 11.1 & 8.4 & 5.8 & 3.3 \\
Imports of goods and services & 14.7 & 9.6 & 3.3 & 2.8 \\
GDP - change from previous year & 7.4 & 6.0 & 2.7 & 2.9 \\
Consumer price inflation (annual rate) & 1.7 & 1.9 & 2.9 & 3.4 \\
Unemployment rate (annual average) & 3.0 & 2.6 & 5.0 & 5.3 \\
Current account balance (\% of GDP) & 8.0 & 5.8 & & \\
\hline
\end{tabular}

Source: Statistics Iceland, May 2016, Ministry of Finance and Economic Affairs. 



\section{Norway}

\subsection{Economic outlook}

The drop in oil prices three years ago spurred a major economic setback, and for some time the Norwegian economy was characterised by low income rises, redundancies and rising unemployment. This has now turned into an economic recovery that has gradually strengthened. Businesses across the country are reporting higher production, and households have also become more optimistic over the past year. Growth in the Norwegian economy has outpaced expectations so far in 2017, and unemployment is declining. Low interest rates, a distinct improvement in competitiveness, and expansionary fiscal policy have been important drivers.

Improved household purchasing power and higher petroleum investments will strengthen economic growth over the next couple of years. The oil price has almost doubled since the low point in early 2016, and is now close to the historical average since 1970, in real terms. Oil companies have succeeded in cutting costs, making projects profitable at lower prices than was the case only a few years ago.

The economic outlook is also supported by higher growth in the world economy. Mainland businesses may realise higher exports and investments as improved competitiveness continues to filter through. In 2018, we expect the mainland economy to outpace trend growth, capacity utilisation in the economy to increase, and the labour market improvements to continue.

Economic policy has provided a strong impetus to growth. The key interest rate is at a historical low of $0.5 \%$, and fiscal policy has delivered significant and targeted measures. Such a response to the steep decline in oil prices has contributed to the rebound in economic growth.

The Norwegian krone has depreciated considerably in the wake of the oil price decline. This has distinctly improved the competitiveness of export businesses, petroleum industry suppliers and other businesses exposed to international competition in the Norwegian domestic market. Adaptations to improved competitiveness take time, 
but tourism and aquaculture are examples of industries with rapidly increasing revenues. We expect exports and investments to increase gradually.

Low wage increases also serve to improve the competitiveness of Norwegian businesses. In line with the outcome of the wage settlement for sectors exposed to international competition, total annual wage increases are estimated at $2.4 \%$ this year. Nevertheless, the wage costs in Norway remain substantially higher than the average for Norway's trading partners. We expect wage growth to increase somewhat in 2018.

Consumers have become more optimistic about the economic outlook. One reason is that interest rates are low, but the optimism also reflects the improvement in the Norwegian economy. Total household demand for goods and services is expected to pick up in coming years.

The increase in the number of start-up permits for new housing projects is indicative of high housing investment growth this year. Slower increases in housing prices and population point to somewhat lower housing investments ahead, but the level of investments will remain high. After steep rises in housing price growth last year, prices have been falling for the last few months, especially in Oslo. The housing market is currently characterised by the large number of homes for sale, particularly in Oslo. It is not unexpected for price growth to level off after a period of such steep growth. More housing construction may contribute to continued moderate development in housing prices in coming years.

The labour market is improving. Registered unemployment declined for the ninth month in a row in August, comprising $2.6 \%$ of the labour force (seasonally adjusted) in September. The unemployment figure based on Statistics Norway's labour force survey was $4.2 \%$ in July, down from $4.7 \%$ in 2016 . Unemployment is falling all over the country, including southern and western Norway. Employment trends were weak for a long time, but have improved this year according to national accounts. Labour market improvements are expected to continue as economic growth picks up.

Consumer price inflation has abated since last summer, partly reflecting that the depreciation of the krone after the oil price fall is no longer pushing up prices of imported goods. In addition, moderate wage increases are contributing to low inflation. Next year we expect lower electricity prices to contribute to lower increases in consumer prices.

Overall, mainland GDP is forecast to grow by $2.0 \%$ this year, a doubling from 2016. For the next two years, growth is expected to increase to 2.5-2.6 percent, well above trend growth in the economy. 
The output gap is forecast to close gradually in the next few years, as slack in the economy is reduced. Compared to the situation one year ago, a significantly higher proportion of businesses now report that they are operating on maximum capacity, although the percentage is still lower than its historical average.

The Brexit negotiations and uncertainty about the policies of the US administration add uncertainty to the international economic outlook. Protectionism and a higher level of conflict between countries may rapidly undermine world economic growth. In the short term, however, a strong upsurge in optimism amongst businesses and households, especially in Europe, may result in even higher economic growth. The steep increase in credit growth in some countries, including China, adds uncertainty in the medium term.

In Norway, many households have high debt burdens. These households may have to cut back on consumption in the event of an interest rate increase, or if housing prices were to continue falling for a prolonged period. This could inhibit the recovery. On the other hand, the increase in business investment may be stronger than anticipated, after a long period of weak growth.

\subsection{Public finances}

The Norwegian fiscal policy framework insulates the budget from fluctuations in oil and gas revenues. The state's net cash flow from petroleum activities is transferred in full to the Government Pension Fund Global, and the returns are reinvested in the Fund. The use of petroleum revenues, i.e. withdrawals from the Fund, fully covers the non-oil budget deficit. In formulating fiscal policy, petroleum revenue spending is measured by the structural, nonoil budget deficit. The fiscal guidelines stipulate a gradual and sustainable use of petroleum revenues over time in line with the expected real rate of return of the Government Pension Fund Global. The estimated real rate of return has recently been reduced from $4-3 \%$.

In any given year, the use of petroleum revenues can deviate from the $3 \%$ path to help stabilise economic activity and thereby support high capacity utilisation and low unemployment. In the event of large fluctuations in the Fund's value, implications for the use of petroleum revenues will be phased in over several years. 
Percentage change unless stated otherwise

Private consumption

Public consumption

$\begin{array}{rrrr}1.5 & 2.3 & 3.2 & 3.2 \\ 2.1 & 1.7 & 1.2 & . . \\ -0.2 & 3.9 & 2.5 & 3.0 \\ 5.9 & 5.4 & 1.5 & . . \\ -16.9 & -6.5 & 2.2 & 7.7 \\ 2.6 & 3.1 & 2.5 & 2.4 \\ -1.8 & 1.1 & 0.9 & 1.9 \\ -8.2 & 1.7 & 3.8 & 5.0 \\ 2.3 & 3.2 & 3.3 & 3.6 \\ 1.1 & 1.9 & 1.5 & 1.9 \\ 1.0 & 2.0 & 2.5 & 2.6\end{array}$

Gross fixed investment

- Public sector

- Petroleum extraction and pipeline transportation

Demand from Mainland Norway ${ }^{1}$

Exports

Of which: Traditional goods

Imports

Gross domestic product

Of which: Mainland Norway

1.5
2.1
-0.2
5.9
-16.9
2.6
-1.8
-8.2
2.3
1.1
1.0

Labour market

Employment, persons

$\begin{array}{lll}0.3 & 0.7 & 1.1\end{array}$

Unemployment rate, LFS

Unemployment rate, registered

\section{Prices and wages}

Annual wage

$\begin{array}{llll}1.7 & 2.4 & 3.0 & 3.0\end{array}$

Consumer price index (CPI)

Underlying inflation (CPI-ATE)

Oil price (NOK per barrel)2

Interest rates and exchange rates

Three-month money market rates $(\%)^{3}$

$\begin{array}{llll}1.1 & 0.9 & 0.9 & 1.2\end{array}$

Import-weighted exchange rate (yearly change) 4

Main numbers, National budget 2016

Structural, non-oil budget deficit (NOK bn.)

198.7

219.6

231.1

- Fiscal impulse 5

Deviation from $4 \%$ path (expected real return, NOK bn.)

Note: ${ }^{1}$ Excluding inventory changes.

${ }^{2}$ Current prices.

3 Calculation based on forward rates in September.

4 A positive number indicates a depreciation of the krone.

5 Measured by the change in the structural, non-oil deficit as a proportion of trend GDP of Mainland Norway.

${ }^{6}$ For the 2016 and 2017 budgets, the expected real return was calculated to be $4 \%$, so deviations are not included for these years.

Source: Statistics Norway, the Norwegian Labour and Welfare Administration, and Ministry of Finance.

The Government's budget proposal for 2018 implies a neutral fiscal stance, with a fiscal budget stimulus equivalent to less than $0.1 \%$ of trend GDP for mainland Norway. The structural non-oil deficit in 2018 is equivalent to $2.9 \%$ of the Government Pension Fund 
Global. The general tax rate for businesses and workers has been gradually reduced from $28-24 \%$ over the past years. The budget proposal for 2018 includes a lowering of the rate to $23 \%$.

The general government financial balance is estimated at NOK 133.0 billion, equivalent to $3.9 \%$ of GDP.

Recent decades have been a golden period for the Norwegian economy and public finances, and key economic trends have been favourable. However, the tide is now turning. The Government Pension Fund will not continue to grow at the same rate. Returns are expected to be lower than before, and the oil price is not expected to regain its former peaks. The value of the Fund is no longer expected to increase as a portion of output in the mainland economy, so the scope for further expansion of petroleum revenue spending is limited. The average fiscal policy stance in the years ahead should therefore be virtually neutral, while still tailored to the cyclical position of the Norwegian economy in any given year. When the time perspective is extended, the pressure on public finances becomes more severe. 



\section{Sweden}

\subsection{Economic outlook}

Activity level in the Swedish economy is high, and both households and businesses are optimistic about the future. Demand for labour remains high. GDP is expected to grow by $3.1 \%$ in 2017 . The Government's welfare initiatives will contribute to further growth in 2018. Resource utilisation is estimated to be higher than normal in 2017, and is expected to rise further in 2018.

Domestic demand has largely driven growth in recent years. Investments and household and public sector consumption have increased rapidly. For the third consecutive year, GDP is expected to be above $3 \%$ in 2017, which is higher than the average since 1993. By 2018, GDP growth is expected to slow somewhat, due to lower investments. This is explained by the current high level of investments, which results in a rapidly increasing capital stock. In addition, the increase in capacity constraints in the construction sector, such as recruitment difficulties, is limited.

Household consumption grew strongly in the first half of 2017, particularly retail sales. Low interest rates, high levels of household savings, high confidence indicators, and positive labour market trends are indicative of greater consumption in the future so, by 2018 , the rate of household consumption is expected to increase. Consumption per capita is also expected to rise in 2017 and 2018. Public consumption increased by $2.9 \%$ in 2016 , which was the highest rate since 1998 . Consumption grew strongly in both the state and the municipal sector.

Municipal consumption is expected to increase strongly in 2017. The need for municipal services is largely affected by demographic trends, with more children and elderly people in the population. The increase of SEK 10 billion in general government contributions from 2017 will help municipalities meet these needs. The government initiative in the 2018 budget bill in health, education and care further contribute to meeting these needs in the municipal sector in the coming years. Government consumption is expected to fall slightly in 2017 , partly due to reduced costs related to 
migration. However, police and defence items in the 2018 budget bill are expected to increase government consumption in 2018.

Gross fixed capital formation has risen sharply since 2014, especially in housing. The number of housing construction project starts is at its highest level since the Million Programme in the 1970s. Investment share of GDP is at the highest level since the beginning of the 1990s. Due to the high population growth in recent years there is still a great need for housing. Housing investment is therefore expected to continue to grow rapidly in 2017, and is expected to be at a high level in the future due to strained resource utilisation in the construction sector.

High confidence indicators in industry point towards a rapid increase in production in 2017, but industry is expected to meet external demand without extensive new investments. The assessment is supported by the Statistics Sweden (SCB) investment survey, where industrial companies only expect a slight increase in investment volume in 2017 compared with 2016. Public investment is expected to continue to grow at an unimpeded rate in 2017, but is expected to slow somewhat in 2018. The development is primarily driven by major renovation needs regarding older infrastructure and buildings. Overall, investments in the economy are expected to grow more slowly in the future, when the rate of housing construction is dampened.

Exports grew weakly during the first half of 2017, especially exports of services, partly explained by a temporary drop in tourists visiting Sweden. However, conditions for exports of goods have improved and, in the second half of 2017, growth in goods exports is expected to be the strongest since 2011. Furthermore, in the second half of 2017 and the whole of 2018, export growth will continue to benefit from a global investment increase, particularly in Europe. Together with moderate import growth, net exports are expected to make a positive contribution to GDP in 2017 and 2018.

Unemployment has been falling since 2014, and is now at the lowest level since 2008. The decrease has been particularly evident for young people (15-24 years), and youth unemployment is the lowest since 2003. Leading indicators, such as the number of job vacancies and business employment plans according to the Economic Tendency Survey from NIER, indicate that demand for labour remains healthy. The strong economic development and government measures, both implemented and proposed in the 2018 budget bill, mean that unemployment is expected to fall to $5.9 \%$ in 2018 .

The Riksbank is pursuing an expansionary monetary policy aimed at stimulating demand and inflation. The policy rate (repo rate) has been -0.5\% since February 2016. The Riksbank is also implementing a comprehensive programme of government bond 
purchases that will continue until at least the end of 2017. The repo rate is expected to rise at a slow pace in the future. Expectations that the Riksbank will hold the repo rate for a long period have contributed to keeping Swedish bond yields historically very low. Following the US presidential election in autumn 2016, Swedish and many foreign government bond yields rose, partly due to expectations of a more expansive fiscal policy in the United States. However, uncertainty about political developments in the US has held back interest rate increases in the first half of 2017. The gradual global recovery and continued robust growth in the Swedish economy are expected to promote increases in government bond yields.

\subsection{Public finances}

The general government deficit was reduced by $2.5 \%$ of GDP between 2014 and 2016, reaching a surplus of $0.9 \%$ of GDP in 2016. The strong recovery of the Swedish economy and a responsible fiscal policy contributed to this considerable strengthening of the public finances. A large inflow of refugees in 2015 is currently exerting greater pressure on expenditure. It is reasonable to allow exceptional and temporary events of this kind to be accommodated without requiring short-term contractionary budgetary measures. Net lending is positive and public debt low and on a downward trend. There is therefore fiscal capacity to accommodate this expenditure increase in a socially and economically responsible way, without jeopardising the long-term sustainability of public finances.

The Government will continue to pursue a responsible fiscal policy. Refugee-related expenditure is expected to peak in 2017, and then decline. Despite this cost increase, public sector finances are projected to show surpluses amounting to nearly $1 \%$ of GDP or more every year of the forecast period. The cyclically adjusted balance is estimated to remain broadly stable as a share of GDP, and the debt-to-GDP ratio will fall. 
Table 6: Key figures for the Swedish economy

Percentage change unless stated otherwise

\begin{tabular}{|c|c|c|c|c|c|}
\hline GDP & 2.6 & $4 \cdot 5$ & 3.3 & 3.1 & 2.5 \\
\hline Private consumption & 2.1 & 3.1 & 2.1 & 2.4 & 2.9 \\
\hline Public consumption & 1.5 & 2.4 & 3.4 & 0.7 & 1.4 \\
\hline Fixed capital formation & $5 \cdot 5$ & 6.9 & 5.6 & 7.1 & 2.7 \\
\hline Stock building (contribution to growth) & 0.1 & 0.4 & 0.0 & -0.1 & -0.2 \\
\hline Exports & $5 \cdot 3$ & $5 \cdot 7$ & 3.3 & 2.9 & 3.9 \\
\hline Imports & 6.3 & 5.2 & 3.4 & 2.6 & 3.5 \\
\hline Net exports (contribution to growth) & -0.2 & 0.4 & 0.1 & 0.2 & 0.4 \\
\hline Productivity in private sector ${ }^{1,2}$ & 1.5 & $3 \cdot 3$ & 1.7 & 2.0 & 1.8 \\
\hline Hours worked ${ }^{2}$ & 1.8 & 0.9 & 2.1 & 2.0 & 1.3 \\
\hline Employment ${ }^{3}$ & 1.4 & 1.4 & 1.5 & 2.3 & 1.2 \\
\hline Unemployment 4 & 7.9 & 7.4 & 6.9 & 6.6 & 5.9 \\
\hline GDP gap 5 & 2.4 & -0.7 & 0.2 & 0.8 & 1.0 \\
\hline Wages $^{6}$ & 2.8 & 2.4 & 2.4 & 2.7 & 3.0 \\
\hline $\mathrm{CPI} 7$ & -0.2 & 0.0 & 1.0 & 1.6 & 1.7 \\
\hline
\end{tabular}

Note: ${ }^{1}$ Value added at base prices per hour worked.

${ }^{2}$ Calendar adjusted.

${ }^{3} 15-74$ years.

4 Proportion of labour force $15-74$ years.

5 Difference between actual and potential GDP, as a percentage of potential GDP.

${ }^{6}$ According to short-term wage statistics.

7 Annual average.

${ }^{8}$ Consolidated general government, percentage of GDP. Outturn for net lending 2011-2014 has been revised after the publishing of the Budget Bill, net lending 2014 was SEK 67 billion or $1.7 \%$ of GDP.

Source: Statistics Sweden and the Swedish Ministry of Finance.

Public Finances.

Table 7: Estimates from the Budget Bill for 2018

\begin{tabular}{lrrrrrr} 
Key figures & 2015 & 2016 & 2017 & 2018 & 2019 & 2020 \\
Fiscal position & 0.3 & 0.9 & 1.0 & 0.9 & 1.0 & 1.5 \\
Structural balance & 0.1 & 1.0 & 0.8 & 0.6 & 0.7 & 1.1 \\
Consolidated gross debt & 43.9 & 41.6 & 38.6 & 36.5 & 34.4 & 32.0 \\
\hline
\end{tabular}




\section{Sammanfattning}

Denna rapport om den ekonomiska utvecklingen i Norden har tagits fram av Nordiska konjunkturgruppen. De nordiska länderna befinner sig i olika faser av konjunkturcykeln. Dansk BNP-tillväxt är brett baserad, där de största bidragen väntas komma från privat konsumtion och export, samtidigt som investeringar kommer att få en större betydelse under 2018. Den finska ekonomin är inne i en snabb tillväxtperiod. Privat konsumtion, och i viss utsträckning investeringsefterfrågan, kommer att utvecklas långsammare framöver, men exporten väntas å andra sidan ta fart. Den tidigare svaga BNPutvecklingen i Norge har vänt. Målinriktade finanspolitiska åtgärder ha r bidragit till att stärka den ekonomiska tillväxten och minska arbetslösheten. BNP för fastlands-Norge förutses växa snabbare än potentiell tillväxt nästa år. Aktivitetsnivån i den svenska ekonomin är hög. Regeringens välfärdsinitiativ tillsammans med hushållskonsumtion och investeringar väntas bidra till fortsatt stark tillväxt. Den isländska ekonomin växer snabbt. Tillväxten är exportdriven men bidragen från privat konsumtion har ökat som följd av stora löneökningar och låg inflation. 
$\mathbb{1}$

Nordic Council of Ministers

Nordens Hus

Ved Stranden 18

DK-1061 Copenhagen K

www.norden.org

\section{Nordic Economic Outlook 2017}

Nordiska konjunkturgruppen has operated under the Nordic Council of Ministers since 2004 and consists of experts from the Nordic Finance Ministries. The group exchanges information on macroeconomic and structural developments on a continuous basis. The group also prepares the annual Nordic Economic Outlook. 